University of Nebraska - Lincoln

DigitalCommons@University of Nebraska - Lincoln

Publications from USDA-ARS / UNL Faculty

U.S. Department of Agriculture: Agricultural

Research Service, Lincoln, Nebraska

November 1995

\title{
Accuracy of Equations Predicting the Phyllochron of Wheat
}

Gregory S. McMaster

USDA-ARS, greg.mcmaster@ars.usda.gov

Wallace Wilhelm

University of Nebraska-Lincoln, wwilhelm1@unl.edu

Follow this and additional works at: https://digitalcommons.unl.edu/usdaarsfacpub

Part of the Agricultural Science Commons

McMaster, Gregory S. and Wilhelm, Wallace, "Accuracy of Equations Predicting the Phyllochron of Wheat" (1995). Publications from USDA-ARS / UNL Faculty. 79.

https://digitalcommons.unl.edu/usdaarsfacpub/79

This Article is brought to you for free and open access by the U.S. Department of Agriculture: Agricultural Research Service, Lincoln, Nebraska at DigitalCommons@University of Nebraska - Lincoln. It has been accepted for inclusion in Publications from USDA-ARS / UNL Faculty by an authorized administrator of DigitalCommons@University of Nebraska - Lincoln. 


\title{
Accuracy of Equations Predicting the Phyllochron of Wheat
}

\author{
Gregory S. McMaster* and W. W. Wilhelm
}

\begin{abstract}
Predicting the rate of leaf appearance, or phyllochron, aids in understanding and modeling grass development and growth. Nine equations predicting the phyllochron of wheat (Triticum aestivum L.) were evaluated using field data from a variety of locations, cultivars, and management practices. Each equation is referred to by the last name of the first author; if there is more than one equation by the first author, additional descriptors were included. The BAKER and KIRBY equations predict the phyllochron based on changes in daylength following seedling emergence; CAO-TEMP and CAO-DAY use a curvilinear relationship with temperature and daylength, respectively; CAO-T\&D uses the ratio of temperature to daylength; VOLK mathematically refines CAO-T\&D; MIGLIETTA uses an ontogenetic decline in the rate of leaf appearance; and MIGLIETTA-DAY adds photoperiod effects to MIGLIETTA. No equation adequately predicted the phyllochron. The $r^{2}$ values between predicted and measured phyllochron for winter wheat and spring wheat cultivars, respectively, were BAKER $(0.001,0.486), \operatorname{KIRBY}(0.002,0.487)$, CAO-DAY $(0.000$, 0.174), MIGLIETTA-DAY (0.013, 0.008), MIGLIETTA $(0.002$, 0.405), CAO-TEMP (0.100, 0.190), CAO-FIELD (0.078, 0.036), CAOT\&D (0.066, 0.030), and VOLK $(0.119,0.043)$. All equations predicted the phyllochron for spring wheat cultivars better than winter wheat cultivars. BAKER and MIGLIETTA showed no bias towards either over or underestimating the phyllochron; KIRBY tended to overestimate the phyllochron; and the remaining equations were biased towards underestimating the phyllochron. Equations developed from field data had the greatest range of predicted phyllochrons. Based on multiple criteria, the BAKER equation best predicted the phyllochron for the experimental data set. Other factors must be added to the equations to improve predictions. Much opportunity exists to improve our ability to predict the phyllochron.
\end{abstract}

$\mathrm{T}$ HE NOTION of pattern and orderliness in plant development and leaf appearance, the importance of understanding the role of leaf appearance in grass development and growth (Klepper et al., 1984), and attempts to model grass development and growth (e.g., McMaster et al., 1992a; Waldman et al., 1991; Weir et al., 1984) have fostered efforts to predict leaf appearance.

The phyllochron, or rate of leaf appearance, is defined as the time between the appearance of successive leaves on a shoot and is usually expressed in units of growing degree-days (GDD) per leaf. The earliest work on leaf appearance was largely descriptive, concentrating on location in the leaf where growth occurs, rate of elongation, and total number of leaves produced. Crop modeling has spurred interest in deriving equations to predict the phyllochron. Starting in 1980, nine equations have been published to predict the phyllochron of wheat (Table 1).

In 1980, Baker and others published an equation for calculating the phyllochron of winter wheat as a function of the change in daylength immediately following seed-

G.S. McMaster, USDA-ARS, Great Plains Systems Research Unit, P.O. Box E, Fort Collins, CO 80522; and W.W. Wilhelm, USDA-ARS, Soil and Water Conservation Research Unit, 119 Keim Hall, Univ. of Nebraska, Lincoln, NE 68583. Received 11 Mar. 1994. *Corresponding author (greg@gpsrv1.gpsr.colostate.edu).

Published in Crop Sci. 35:30-36 (1995). ling emergence based on one cultivar (Maris Huntsman) grown in England. Two assumptions are that the phyllochron is determined at the time of seedling emergence and that it remains relatively constant during the growing season. Many studies support these assumptions (e.g., Belford et al., 1987; Delécolle et al., 1989; Kirby and Eisenberg, 1966; Malvoisin, 1984; Masle et al., 1989); other studies, primarily growth chamber work, present conflicting results (Baker et al., 1986; Boone and Wall, 1990; Cao and Moss, 1991; Hay and Delécolle, 1989). Experimental results show that as planting date is delayed, the phyllochron decreases (Baker et al., 1980; Jones and Allen, 1986; Kirby and Perry, 1987; Kirby et al., 1982, 1985). Because daylength changes with planting date, this equation changes the predicted phyllochron so that planting date effects are incorporated. In 1987 , Kirby and Perry published a similar equation to Baker et al. (1980) but based their equation on Australian cultivars.

Cao and Moss $(1989 a, b, c)$ conducted a series of growth chamber experiments examining the detailed phyllochron response of four winter wheat and four spring barley cultivars to different temperatures, daylengths, and their interactions. Equations were derived for each cultivar and across cultivars. The experiment followed the first four leaves, which may have impacted the observed rates because the seed embryo typically has 3 to 4 leaf primordia (Baker and Gallagher, 1983; Bonnett, 1966; Lersten, 1987; Malvoisin, 1984) and early leaves may appear at a faster rate than those leaves whose primordia have not been initiated in the embryo. The intention of their experiment was not to predict the phyllochron under field conditions but rather to understand the effects of temperature and daylength on the phyllochron (W. Cao, 1992, personal communication).

The Cao and Moss (1989a) equation assumes a curvilinear relationship with temperature. This is an important departure from the assumption of Baker et al. (1980) and Kirby and Perry (1987) of a linear relationship with temperature. This approach allows the phyllochron to vary through time as temperature varies, and therefore does not assume a relatively constant phyllochron that is set early in plant development. The phyllochron increases with temperature up to a maximum of $\approx 20^{\circ} \mathrm{C}$. There fore, under many field conditions in the northern hemisphere, the phyllochron will decrease with later fall planting dates for winter wheat, but for spring plantings, the phyllochron will increase with later planting dates. The

Abbreviations: BAKER, Equation from Baker et al., 1980; CAO-DAY, Equation from Cao and Moss (1989b); CAO-FIELD, Equation from Cao and Moss (1991); CAO-T\&D, Equation from Cao and Moss (1989c); CAO-TEMP, Equation from Cao and Moss (1989a); GDD, growing degree-days; KIRBY, Equation from Kirby and Perry (1987); LER, leaf emergence rate; MIGLIETTA, Equation from Miglietta (1991a); MIGLIETTA-DAY, Equation from Miglietta (1991b); RMSE, root mean square error; SARES, sum of the absolute residuals; SRES, sum of the residuals; VOLK, Equation from Volk and Bugbee (1991); CV, coefficient of variation. 
Table 1. Equations that predict the phyllochron of wheat.

\begin{tabular}{|c|c|c|}
\hline Equation & Source & Phyllochron equation $\dagger$ \\
\hline BAKER & $\begin{array}{l}\text { Baker et al. (1980) and C.K. Baker (personal } \\
\text { communication, 1990) }\end{array}$ & $P=1.0 /(0.0104+0.026 \Delta)$ \\
\hline KIRBY & Kirby and Perry (1987) & $P=1.0 /(0.00949+0.000988 \Delta)$ \\
\hline CAO-TEMP & Cao and Moss (1989a) & $P=45.6073 \times \mathrm{e}(0.0374 T)$ \\
\hline CAO-DAY & Cao and Moss (1989b) & $P=(268.012+58.487 D) / D$ \\
\hline CAO-T\&D & Cao and Moss (1989c) & $P=50.5797+27.2383(T / D)$ \\
\hline VOLK & Volk and Bugbee (1991) & $P=T /(0.27((T / 22)(2-(T / 22)))(\mathrm{D} /(2.4+D)))$ \\
\hline CAO-FIELD & Cao and Moss (1991) & $P=65.210+22.434(T / D)$ \\
\hline MIGLIETTA & Miglietta (1991a) & $\begin{array}{l}\text { LER }=(0.038+0.0149 T)(1+0.03(N+1)) \\
\text { When } \Sigma \text { LER, calculated daily, is }>1 \text {, then } P \text { is calculated for that leaf. }\end{array}$ \\
\hline MIGLIETTA-DAY & Miglietta (1991b) & $P=T(6.5+1.61+L) e(-0.25 D)$ \\
\hline
\end{tabular}

$\dagger$ Definition of symbols: $P=$ Phyllochron (degree days per leaf); $T=$ Average daily temperature (degree $C) ; D=$ Length of daylight $(\mathrm{h}) ; \Delta=$ change in day length from day to day $_{n+1}$, with day $_{n}$ being day of seedling emergence $(h) ; L=$ Latitude of site; LER = Leaf emergence rate (days per leaf); $N=$ The number of leaves that have already emerged.

CAO-TEMP equation will therefore not always follow the reported response of decreasing phyllochrons with later planting dates.

The Cao and Moss (1989b) equation uses the same approach as the Cao and Moss (1989a) equation, except the second equation is based on a curvilinear relationship with daylength rather than temperature. Because the phyllochron decreases with increasing photoperiod, CAO-DAY predicts an increase in the phyllochron for later planting dates in the fall but a decrease for later planting dates in spring.

The third equation (Cao and Moss, 1989c) is based on the daily degree-days divided by daylength, which they call the thermal/photo ratio. They found a linear relationship between this ratio and the phyllochron with all temperature-daylength combinations. The CAO$T \& D$ equation will not always predict a decrease in the phyllochron with later planting dates because temperature and photoperiod relationships do not typically follow a consistent pattern in the field.

Volk and Bugbee (1991) mathematically refined the equations of Cao and Moss (1989a,b,c, specifically $1989 \mathrm{c})$. Volk and Bugbee also added light intensity effects.

In 1991, Cao and Moss extended their earlier work (Cao and Moss, 1989a,b,c) to better predict the phyllochron in the field. They conducted two experiments with different planting dates: (i) a field planting and (ii) potted plants placed in the field. The resulting equation used the thermal/photo ratio concept introduced in $\mathrm{Cao}$ and Moss (1989c) and incorporated an additional refinement to previous work by shifting the phyllochron once 600 GDD had accumulated, which coincided with the period of double ridge formation.

The Miglietta (1991a) equation is based on an ontogenetic decline in the rate of leaf appearance. Miglietta proposed that ontogenetic decline explains the observed decrease in the phyllochron with later sowing dates. Both laboratory and field data collected in Italy and England were used in developing the equation. The number of initiated leaf primordia is calculated as the sum of daily rates of initiation, which are a linear function of air temperature. The phyllochron is then equal to the initiation rate of leaf primordia minus a term depending on the number of emerged leaves. Miglietta (1991b) extended his earlier work (Miglietta, 1991a) by incorporating photoperiod effects.
In this manuscript, we evaluate these equations using published data from several cultivars grown in field studies at several locations in the USA, Canada, and South Africa.

\section{METHODS}

\section{Equations Evaluated}

Nine equations were evaluated (Table 1). All equations predict a different phyllochron for each leaf, except for the Baker et al. (1980) and Kirby and Perry (1987) equations, which predict a constant phyllochron through the growing season and assume that the phyllochron is set at emergence. Because many of the validation data sets had only a mean phyllochron for all leaves produced during the growing season, we took the mean of the predicted phyllochrons for each leaf in evaluating the equations. We also limited our evaluation of predicted phyllochron to that period for which we had obtained field measurements.

\section{BAKER Equation}

Because this equation contained several misprints, particularly in the coefficients (Baker et al., 1980), the corrected equation was used in this paper (C.K. Baker, 1990, personal communication).

\section{KIRBY Equation}

The coefficients used in the Kirby equation (Kirby and Perry, 1987) are for the spring wheat cultivar Gamenya, grown in Western Australia.

\section{CAO-TEMP, CAO-DAY, and CAO-T\&D Equations}

For all three equations (CAO-TEMP [Cao and Moss, 1989a], CAO-DAY [Cao and Moss, 1989b], and CAO-T\&D [Cao and Moss, 1989c]), we combined the data for all wheat cultivars in determining the coefficients.

\section{VOLK Equation}

Volk and Bugbee (1991) provided a refinement by adding light intensity effects to Cao and Moss (1989c). We did not evaluate this refinement because light intensity data often were not available for our field validation data sets.

\section{CAO-FIELD Equation}

Several simplifications were made to the CAO-FIELD equation (Cao and Moss, 1991). (i) We combined the two winter cultivars of Stephens and Yamhill from the field experiment 
in determining the coefficients and did not use the potted plants data. (ii) Cao and Moss (1991) presented different equations for each of four planting dates (24 Oct., 14 Nov., 19 Jan., 6 Feb.). Because they did not provide a means to interpolate between planting dates or for planting dates outside of the observed range, we used the 24 Oct. equation for fall plantings and the $6 \mathrm{Feb}$. equation for spring plantings for several data sets (no validation data sets had November, December, or January planting dates). Using the equations for these two dates did not significantly alter the predictive accuracy of using an equation calibrated for a different planting date that was closer to the observed planting date. (iii) It made little practical difference in changing the phyllochron after $600 \mathrm{GDD}$, so we did not include a shift in the phyllochron after 600 GDD.

One ramification of these simplifications is that the phyllochron will not change as much during the growing season as Cao and Moss would normally predict. Another ramification is that if the phyllochron is predicted for early fall plantings and compared with observed phyllochrons in the fall, the modified CAO-FIELD equation will be biased towards predicting a slightly shorter phyllochron than Cao and Moss showed.

\section{Validation Data Sets}

Data sets covered a large range of locations, cultural practices, treatments, and cultivars (Table 2). There were 24 winter wheat and 15 spring wheat observed phyllochrons used. In collating these data sets, a number of issues and problems needed to be addressed.

When the date of $50 \%$ seedling emergence was not always known, we assumed $50 \%$ seedling emergence $10 \mathrm{~d}$ after planting.

When data sets contained observed phyllochron or Haun growth stage (Haun, 1973) values through time, we had to determine which sampling dates to use in computing the phyllochron. Generally, the mean phyllochron of all observation dates was computed. One variation on this approach was for winter wheat where either the seedling emergence date or the fall/winter phyllochron values were uncertain. In these cases,

Table 2. Validation data sets and contributors used to evaluate the equations.

\begin{tabular}{|c|c|c|}
\hline Location & Treatments & Contributors \\
\hline \multicolumn{3}{|c|}{ Spring wheat } \\
\hline Fort Collins, Co & Cultivars & $\begin{array}{l}\text { G.S. McMaster, } \\
\text { W. Wilhelm }\end{array}$ \\
\hline Mandan, ND & $\mathrm{N}$, cultivars, water & $\begin{array}{l}\text { A. Bauer, A.L. Black, } \\
\text { A.B. Frank }\end{array}$ \\
\hline $\begin{array}{l}\text { Phoenix, AZ } \\
\text { Pretoria, South Africa } \\
\text { Riverside, CA }\end{array}$ & $\begin{array}{l}\text { Cultivars } \\
\text { Water, N } \\
\text { Salinity, cultivars }\end{array}$ & $\begin{array}{l}\text { J.T. Baker } \\
\text { S. Walker } \\
\text { E.V. Maas, } \\
\text { C.M. Grieve }\end{array}$ \\
\hline \multicolumn{3}{|c|}{ Winter wheat } \\
\hline Fort Collines, CO & $\begin{array}{l}\text { Water, } N \text {, cultivars, } \\
\text { tillage, residue } \\
\text { cover, planting date }\end{array}$ & $\begin{array}{l}\text { G.S. McMaster, } \\
\text { W. Wilhelm }\end{array}$ \\
\hline $\begin{array}{l}\text { Lethbridge, Canada } \\
\text { Mandan, ND }\end{array}$ & $\begin{array}{l}\mathbf{N} \text {, cultivars } \\
\mathbf{N} \text {, cultivars, water }\end{array}$ & $\begin{array}{l}\text { D.J. Major } \\
\text { A. Bauer, A.L. Black, } \\
\text { A.B. Frank }\end{array}$ \\
\hline Manhattan, KS & Water, $N$, cultivars & $\begin{array}{l}\text { J.T. Baker, E.T. } \\
\text { Kanemasu }\end{array}$ \\
\hline Pendleton, OR & $\begin{array}{l}\mathrm{N} \text {, cultivars, } \\
\text { planting date }\end{array}$ & $\begin{array}{l}\text { B. Klepper, } \\
\text { R.W. Rickman }\end{array}$ \\
\hline Treyon, NE & $\mathrm{N}$, cultivars & $\begin{array}{l}\text { B.L. Blad, K.G. } \\
\text { Hubbard }\end{array}$ \\
\hline \multicolumn{3}{|c|}{ Durum wheat } \\
\hline Mandan, ND & $\mathrm{N}$, cultivars, water & $\begin{array}{l}\text { A. Bauer, A.L. Black, } \\
\text { A.B. Frank }\end{array}$ \\
\hline
\end{tabular}

the phyllochron values for the spring period were used. If the spring values seemed questionable, the final estimate was used because this estimate was least influenced by errors in seedling emergence date and by fall/winter problems of estimating the phyllochron.

When data sets had several cultivars, we pooled the cultivars because none of the equations predicted different phyllochrons for specific cultivars. We also pooled different treatments, such as fertilizer and tillage, because the equations could not predict these kind of treatment effects, and usually, the treatments had little effect on the phyllochron.

Four data sets had very high observed phyllochrons of 165 , 175,204 , and 229 GDD leaf $^{-1}$. Because there was concern whether these phyllochrons were accurate, we analyzed the results with and without them. Unless otherwise stated, results included all observed phyllochrons.

\section{Statistical Methods}

One evaluation technique used was to calculate the root mean square error (RMSE), sum of the residuals (SRES), and sum of the absolute residuals (SARES; McMaster and Smika, 1988). The RMSE is essentially a variance estimate calculated by comparing the observed to predicted phyllochrons. The SRES and SARES can assess the tendency of the equations to over or underpredict the phyllochron. If SRES is positive and large compared with SARES, then the equation is biased towards underpredicting the phyllochron. Conversely, if SRES is a large negative number compared with SARES, then the equation tends to overpredict the phyllochron.

\section{RESULTS AND DISCUSSION}

Regardless of technique used to evaluate the equations, all equations were unable to accurately predict the phyllochron for the majority of field conditions when combining all cultivars. There was considerable scatter about the $1: 1$ line when comparing the observed to predicted phyllochrons (Fig. 1). Most equations tend to underpredict the phyllochron, especially equations based on growth chamber data such as CAO-T\&D, CAO-TEMP, and VOLK.

A commonly used technique to measure the fit to the 1:1 line is to calculate simple linear regressions. All $r^{2}$ values were $<0.1$ when combining all cultivars. The highest $r^{2}$ values were for the BAKER and KIRBY equations, with the CAO-DAY, MIGLIETTA, and MIGLIETTA-DAY equations forming the next group (Table 3 ). The remaining equations had very low $r^{2}$ values. All equations had $r^{2}$ values $<0.5$ for spring wheat and 0.12 for winter wheat.

No equation had a slope significantly greater than 0 (Table 3). A slope of 1 and y-intercept of 0 would be a perfect prediction. If we assume that the slope of the line is zero, then the $y$-intercept estimates the mean phyllochron predicted by each equation for all data sets. All equations based on field data had higher mean predicted phyllochrons than those based on growth chamber results. The KIRBY and MIGLIETTA equations clearly predicted the largest phyllochrons (Fig. 1).

Another technique to assess the fit to the 1:1 line uses the RMSE. The RMSE ranged from 33.4 to 53.1 for the Baker and Volk equations, respectively, when combining all cultivars (Table 4). If the questionable observed 


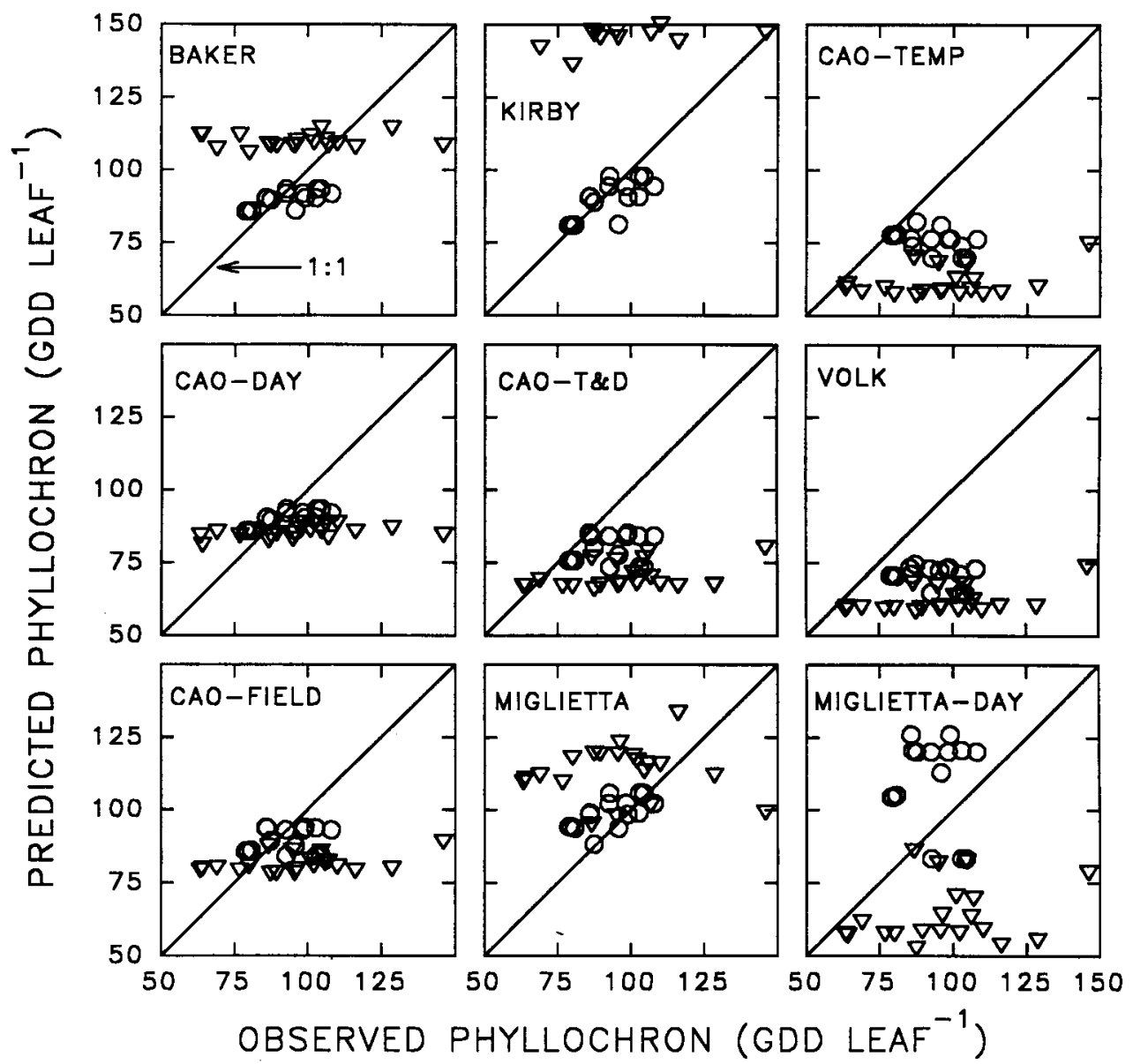

Fig. 1. Comparison of observed to predicted phyllochrons for nine equations. The acronym for each equation is listed inside each graph (see text for acronym definition). All observed (four points) and predicted phyllochrons $>150$ growth degree days (GDD) per leaf are omitted from the graphs. Only the KIRBY equation had predicted values >150 GDD (11 points). The MIGLIETTA-DAY equation had one predicted phyllochron <50 GDD. Spring wheat cultivars are denoted with circles and winter wheat cultivars with triangles.

phyllochrons (above $150 \mathrm{GDD}^{\text {leaf }}{ }^{-1}$ ) are omitted, the RMSE decreases substantially for all equations, except KIRBY, and the rankings are changed slightly.

The simple linear regression and RMSE techniques both confirm that no equation had a good fit to the $1: 1$

Table 3. Simple linear regression results for phyllochron equation predictions.

\begin{tabular}{|c|c|c|c|c|c|c|}
\hline \multirow[b]{3}{*}{ Equation } & \multicolumn{4}{|c|}{ All wheats } & \multicolumn{2}{|c|}{$\begin{array}{l}\text { All observed } \\
\text { phyllochrons }\end{array}$} \\
\hline & \multicolumn{3}{|c|}{$\begin{array}{c}\text { All observed } \\
\text { phyllochrons } \dagger\end{array}$} & \multirow{2}{*}{$\begin{array}{l}\begin{array}{l}\text { Phyllochrons } \\
\leq 165 \text { GDD } \ddagger\end{array} \\
r^{2}\end{array}$} & \multirow{2}{*}{$\frac{\begin{array}{l}\text { Winter } \\
\text { wheat }\end{array}}{r^{2} \dagger}$} & \multirow{2}{*}{$\frac{\begin{array}{l}\text { Sprin } \\
\text { whea }\end{array}}{r^{2}}$} \\
\hline & $r^{2}$ & $A 8$ & $B 9$ & & & \\
\hline BAI & 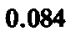 & 93 & & 0 & 0.001 & 0.4 \\
\hline KIRE & & 101 & & & & 0.4 \\
\hline CAO-DAY & 0.056 & 80.6 & 0.02 & 0.100 & 0.000 & 0.1 \\
\hline MIG-DAY & 0.041 & 101.6 & -0.15 & 0.001 & 0.013 & 0.0 \\
\hline MIGLIETTA & 0.037 & 97.4 & 0.06 & 0.018 & 0.002 & 0.4 \\
\hline CAO-TEMP & 0.010 & 69.6 & -0.02 & 0.001 & 0.100 & 0.1 \\
\hline CAO-FIELD & 0.003 & 85.3 & -0.01 & 0.017 & 0.078 & 0.03 \\
\hline CAO-T\&D & 0.002 & 74.8 & -0.01 & 0.028 & 0.066 & 0.0 \\
\hline VOLK & 0.0 & 65.7 & -0.00 & 0.017 & 0.119 & 0.043 \\
\hline
\end{tabular}

$\dagger$ All predicted vs. observed phyllochron comparisons were used, including phyllochrons $>165$ GDD $^{\text {leaf }}{ }^{-1}$.

$\ddagger$ GDD = growing degree-days.

$\$ A$ is the y-intercept.

I $B$ is the slope. line. Overall, the rankings of the equations were about the same for either technique, with notable exceptions being the higher $r^{2}$ ranking for the KIRBY and MIGLIETTA-DAY equations and lower $r^{2}$ ranking for the CAO-FIELD equation. Again, equations based on field data tended to predict the phyllochron better than growth chamber based equations for both winter and spring wheat.

The SRES and SARES calculations were used to assess the tendency to over or underpredict the phyllochron. The MIGLIETTA and BAKER equations did not have a tendency to over or underpredict the phyllochron (Table 4). The KIRBY equation tended to overpredict the phyllochron, and the remaining equations tended to underpredict the phyllochron. The four equations based on growth chamber data underpredicted the phyllochron, often considerably so.

The observed winter wheat phyllochrons had greater range (63-229 GDD leaf ${ }^{-1}$ ) and a higher mean (112.5 GDD leaf ${ }^{-1}$ ) than spring wheat (79-108 GDD leaf ${ }^{-1}$, mean $=93.0 \mathrm{GDD} \mathrm{leaf}^{-1}$; Table 5). Given that equations based on field data had the greatest range of predicted phyllochrons (except for CAO-FIELD) and the mean predicted phyllochrons for all field-based equations were 
Table 4. Evaluation results for each equation.

\begin{tabular}{|c|c|c|c|c|c|c|}
\hline \multirow[b]{3}{*}{ Equation } & \multicolumn{4}{|c|}{ All wheats } & \multicolumn{2}{|c|}{$\begin{array}{c}\text { All observed } \\
\text { phyllochrons } \dagger\end{array}$} \\
\hline & \multicolumn{3}{|c|}{ All observed phyllochrons $\dagger$} & \multirow{2}{*}{$\begin{array}{c}\begin{array}{c}\text { Observed } \\
\text { Phyllochrons } \\
\leq 165 \text { GDD } \ddagger\end{array} \\
\text { RMSE } \\
\end{array}$} & \multirow{2}{*}{$\begin{array}{l}\text { Winter } \\
\text { wheat }\end{array}$} & \multirow{2}{*}{$\begin{array}{l}\text { Spring } \\
\text { wheat } \\
\text { RMSE }\end{array}$} \\
\hline & RMSE\& & SRESq & SARES\# & & & \\
\hline $\begin{array}{l}\text { BAKER } \\
\text { MIGLIETTA } \\
\text { CAO-FIELD } \\
\text { CAO-DAY } \\
\text { KIRBY } \\
\text { CAO-T\&D } \\
\text { CAO-TEMP } \\
\text { MIGLIETTA-DAY } \\
\text { VOLK }\end{array}$ & $\begin{array}{l}33.4 \\
34.4 \\
41.0 \\
44.4 \\
46.1 \\
47.2 \\
52.6 \\
53.0 \\
53.1\end{array}$ & $\begin{array}{r}109.7 \\
-99.9 \\
801.4 \\
849.9 \\
-920.8 \\
1209.3 \\
1478.6 \\
916.9 \\
1545.6\end{array}$ & \begin{tabular}{r|}
830.1 \\
907.7 \\
965.0 \\
984.5 \\
1359.2 \\
1222.7 \\
1478.6 \\
1526.7 \\
1545.6
\end{tabular} & $\begin{array}{l}19.1 \\
21.9 \\
19.5 \\
19.7 \\
45.6 \\
26.5 \\
32.9 \\
33.1 \\
33.7\end{array}$ & $\begin{array}{l}42.1 \\
43.2 \\
51.6 \\
50.1 \\
58.5 \\
58.8 \\
65.1 \\
64.6 \\
64.6\end{array}$ & $\begin{array}{r}8.2 \\
9.2 \\
10.1 \\
15.5 \\
7.2 \\
16.3 \\
20.6 \\
25.0 \\
24.6\end{array}$ \\
\hline
\end{tabular}

† All predicted vs. observed phyllochrons were used, including phyllochrons $>165$ GDD leaf $^{-1}$.

$\ddagger$ GDD = growing degree days.

\& RMSE = root mean square error

I SRES $=$ sum of the residuals.

\# SARES = sum of the absolute residuals.

closest to the mean observed phyllochron for all observations (105.0 GDD), the field-based equations best predicted the phyllochrons across the broad range of cultivars tested. Figure 1 and Table 4 show that the BAKER, KIRBY, and MIGLIETTA equations predicted phyllochrons for spring wheat cultivars better than winter wheat cultivars. The CAO-TEMP, CAO-DAY, CAO-T\&D, VOLK, CAO-FIELD, and MIGLIETTA-DAY equations show little distinction between predicting spring or winter wheat phyllochrons, although more predicted phyllochrons for spring wheat fall near the 1:1 line than predicted winter wheat phyllochrons. The BAKER and KIRBY equations use the same concept in predicting the phyllochron, but the BAKER equation was parameterized for a winter wheat cultivar and KIRBY for a spring wheat cultivar. The KIRBY equation did not predict winter wheat phyllochrons very well (Fig. 1), but perhaps if the equation was reparameterized for winter wheat phyllochrons, the fit to the 1:1 line might be improved. The problem of many equations predicting a narrow range of phyllochrons would still remain.

The preceding results have compared the equations among different site-years. It also is interesting to examine how the equations predicted the phyllochron for different leaves in a single growing season (Table 6). Although Table 6 shows just 1 yr (1981), the coefficient of variation $(\mathrm{CV})$ calculated for it was similar to the

Table 5. Range of predicted phyllochrons using all of the observed data sets.

\begin{tabular}{lccc}
\hline & \multicolumn{3}{c}{ Range of predicted phyllochrons } \\
\cline { 2 - 4 } Equation & All wheats & Winter wheats & Spring wheats \\
\hline & & GDD leaf ${ }^{-1}$ & \\
OBSERVED & $63-229$ & $63-229$ & $79-108$ \\
KIRBY & $81-174$ & $136-174$ & $81-98$ \\
MIGLIETTA-DAY & $40-126$ & $40-90$ & $83-126$ \\
MIGLIETTA & $88-133$ & $95-133$ & $88-106$ \\
BAKER & $86-114$ & $105-114$ & $86-93$ \\
CAO-TEMP & $56-82$ & $56-75$ & $70-82$ \\
CAO-T\&D & $66-85$ & $66-80$ & $74-85$ \\
VOLK & $58-74$ & $58-74$ & $65-74$ \\
CAO-FIELD & $78-94$ & $78-89$ & $84-94$ \\
CAO-DAY & $76-89$ & $81-89$ & $76-84$ \\
\hline
\end{tabular}

† GDD = growing degree-days. mean CV calculated for all of the years. The BAKER and KIRBY equations predict a constant phyllochron during the growing season, so there was no $\mathrm{CV}$. For the remaining equations, the CAO-DAY equation had very little variation in the phyllochron among leaves. All other equations, except MIGLIETTA-DAY, had similar variation in predicting the phyllochron within a growing season. The MIGLIETTA-DAY equation had the widest varying phyllochrons, and the pattern of variation was not consistent, resulting in high $\mathrm{CV}$. The variation around the mean CV was very similar for all equations (data not shown), suggesting the unusual conditions did not occasionally result in widely varying phyllochrons during a growing season.

Normally, the mean phyllochron decreases with later planting dates (Jones and Allen, 1986; Kirby et al., 1982, 1985). All equations except CAO-DAY and MIGLIETTA were able to simulate this trend for fall plantings (data not shown). The BAKER and KIRBY equations are based on the change in daylength at seedling emergence, and therefore, must predict this relationship. The KIRBY equation showed much more sensitivity than the BAKER equation, because the BAKER equation predicted very little change in the phyllochron during September and October at latitudes from 35 to $45^{\circ} \mathrm{N}$. For spring plantings, the ability of many of the equations to predict a decreased phyllochron with later planting dates was not consistent.

There are a number of reasons why the equations did not adequately predict the phyllochron across the range of observed phyllochrons. Uncertainty in the observed data exists, and a number of assumptions were necessary to derive some of the observed phyllochrons. Further, some observed phyllochrons were unusually large $(>165$ GDD leaf ${ }^{-1}$ ), exceeding the normally reported phyllochron range.

Most equations do not account for cultivar differences in the phyllochron. It is well established that the phyllochron varies among cultivars (Baker et al., 1986; Frank and Bauer, 1995; McMaster et al., 1992b). The difficulty with trying to parameterize the equations for specific cultivars is that it is not known a priori what the phylloch- 
Table 6. Predicted phyllochron of leaves during a growing season for each equation. The data set is from 1981 Mandan, ND testing different spring wheat cultivars. The mean observed phyllochron for all cultivars was 78.8 growing degree days (GDD) leaf $^{-1}$, with little variation among the leaves during the growing season.

\begin{tabular}{|c|c|c|c|c|c|c|c|c|c|}
\hline \multirow{2}{*}{$\begin{array}{l}\text { Leaf } \\
\text { number }\end{array}$} & \multicolumn{9}{|c|}{ Equation } \\
\hline & BAKER & KIRBY & CAO-DAY & CAO-FIELD & VOLK & CAO-T\&D & CAO-TEMP & MIGLIETTA & MIGLIETTA-DAY \\
\hline \multicolumn{10}{|c|}{ leaf ${ }^{-1}$} \\
\hline 1 & 85.8 & 80.9 & 77.1 & 84.9 & 67.9 & 75.2 & 74.5 & 88.6 & 91.4 \\
\hline 2 & 85.8 & 80.9 & 76.8 & 80.5 & 59.4 & 67.9 & 65.2 & 95.3 & 86.8 \\
\hline 3 & 85.8 & 80.9 & 76.5 & 88.3 & 69.4 & 76.6 & 78.2 & 91.4 & 103.0 \\
\hline 4 & 85.8 & 80.9 & 76.3 & 83.5 & 76.8 & 73.9 & 75.2 & 89.2 & 113.9 \\
\hline 5 & 85.8 & 80.9 & 76.1 & 88.9 & 66.6 & 78.7 & 82.6 & 101.1 & 123.2 \\
\hline 6 & 85.8 & 80.9 & 75.9 & 88.4 & 73.3 & 80.1 & 85.6 & 94.5 & 107.7 \\
\hline 7 & 85.8 & 80.9 & 75.8 & 85.4 & 78.8 & 78.1 & 82.3 & 98.8 & 109.5 \\
\hline 8 & 85.8 & 80.9 & 75.7 & 86.0 & 71.4 & 74.8 & 77.6 & 106.1 & 151.3 \\
\hline Mean & 85.8 & 80.9 & 76.3 & 85.7 & 70.5 & 75.7 & 77.7 & 94.1 & 104.3 \\
\hline CV, \% & 0.0 & 0.0 & 0.7 & 2.9 & 8.7 & 5.0 & 8.2 & 6.1 & 20.1 \\
\hline $\mathrm{CV}$ & 0.0 & 0.0 & 1.6 & 6.4 & 8.5 & 9.3 & 11.0 & 12.8 & 32.7 \\
\hline
\end{tabular}

ron will be for one cultivar relative to other cultivars. There seems to be no relationship with height class, semi-dwarfing genes, maturity class, or vernalization requirement (McMaster et al., 1992b). Given the vast number of cultivars around the world, unless a general pattern among cultivars can be determined, it will be unrealistic to expect parameterizing the equations for more than a few major cultivars within a region.

A wide variety of field conditions were represented in the validation data sets. A number of factors other than temperature and photoperiod have been reported that can affect the phyllochron (Wilhelm and McMaster, 1995), including water (Baker et al., 1986; Bauer et al., 1984; Krenzer et al., 1991), N (Bauer et al., 1984; Frank and Bauer, 1982; Longnecker et al., 1993), salinity (Grieve et al., 1993; Maas and Grieve, 1990), $\mathrm{CO}_{2}$ (Boone and Wall, 1990; LeCain et al., 1992), light quality (Barnes and Bugbee, 1991; Bugbee and Salisbury, 1988; Skinner and Simmons, 1993), light intensity (Bugbee and Salisbury, 1988; Friend et al., 1963; Masle et al., 1989), soil strength (Masle and Passioura, 1987), planting depth (Kirby, 1993), and seed size (Peterson et al., 1989). No equation evaluated considers these factors. However, there is a problem with incorporating these factors into the equations. Water has a positive relationship and air $\left[\mathrm{CO}_{2}\right]$ has a negative relationship with the phyllochron. Many equations, especially the equations based on growth chamber data and the CAOFIELD equation, predicted too low of a phyllochron. Adding these relationships will only worsen the predictions because as water stress or increased air $\left[\mathrm{CO}_{2}\right]$ is added to the equations, the phyllochron should be decreased.

All equations that use temperature use air temperature above the canopy. Until jointing, the shoot apex is below the soil surface. The assumption is that there is a strict correlation between air, soil, and shoot apex temperature. We know that this is not always the case, especially for soil management studies that alter the residue cover and tillage practices (e.g., Gupta et al., 1981, 1983).

Many equations are based on a linear relationship with temperature. Although this is not theoretically true, because field conditions are highly variable in temperature, this is not an unreasonable assumption for predictive purposes. The assumption becomes less reasonable as the daily temperature fluctuations decrease at a location with time. Conversely, the assumption probably becomes more reasonable when considering that the average daily temperature is simply determined from daily maximum and minimum temperatures and is a crude approximation of average daily temperature. In fact, it is not clear whether daily temperature is a better thermal estimate than using either the maximum or minimum temperature alone.

Considerable debate exists on how constant the phyllochron is among leaves during a growing season. Clearly, if the measurements are sufficiently accurate, there does seem to be variation among the leaves, but often in the field, a relatively constant phyllochron is observed, except for an occasional shift around the time of double ridge. Only the CAO-FIELD equation predicts a shift in the phyllochron at double ridge, and in fact, the equation requires a shift to occur, which is normally not observed in the field.

In conclusion, based on multiple criteria, the BAKER equation best predicted the phyllochron for the experimental data set, followed closely by KIRBY and MIGLIETTA. However, $r^{2}$ values for all equations were $<0.5$ for spring wheat and $<0.12$ for winter wheat. Although some equations result in adequate prediction of the phyllochron for some data sets, no one equation provided adequate prediction for all data sets. Clearly, there is ample opportunity to increase our ability to predict the phyllochron and this is a ripe area for more research.

\section{ACKNOWLEDGMENTS}

D. Engert provided invaluable assistance in writing the computer program to evaluate the equations. Grateful acknowledgment is extended to all scientists listed in Table 2 who contributed data sets and J. Benjamin, J. Morgan, and J. Read for collaboration.

\section{REFERENCES}

Baker, C.K., and J.N. Gallagher. 1983. The development of winter wheat in the field. 1. Relation between apical development and plant morphology within and between seasons. J. Agric. Sci. (Cambridge) 101:327-335.

Baker, C.K., J.N. Gallagher, and J.L. Monteith. 1980. Daylength change and leaf appearance in winter wheat. Plant Cell Environ. 3:285-287.

Baker, J.T., P.J. Pinter, Jr., R.J. Reginato, and E.T. Kanemasu. 
1986. Effects of temperature on leaf appearance in spring and winter wheat cultivars. Agron. J. 78:605-613.

Barnes, C., and B. Bugbee. 1991. Morphological response of wheat to changes in phytochrome photoequilibrium. Plant Physiol. 97: $359-365$.

Bauer, A., A.B. Frank, and A.L. Black. 1984. Estimation of spring wheat leaf growth rates and anthesis from air temperature. Agron. J. 76:829-835.

Belford, R.K., B. Klepper, and R.W. Rickman. 1987. Studies of intact shoot-root systems of field-grown winter wheat. II. Root and shoot developmental patterns as related to nitrogen fertilizer. Agron. J. 79:310-319.

Bonnett, O.T. 1966. Inflorescences of maize, wheat, rye, barley, and oats: Their initiation and development. Illinois Agric. Exp. Stn. Bull. 721. Urbana, IL.

Boone, M.Y.L., and G.W. Wall. 1990. $\mathrm{CO}_{2}$ enrichment and temperature effects on spring wheat. IV. Phyllochron intervals. p. 14. In Agronomy abstracts. ASA, Madison, WI.

Bugbee, B.G., and F.B. Salisbury. 1988. Exploring the limits of crop productivity: 1. Photosynthetic efficiency of wheat in high irradiance environments. Plant Physiol. 88:869-878.

Cao, W., and D.N. Moss. 1989a. Temperature effect on leaf emergence and phyllochron in wheat and barley. Crop Sci. 29:10181021.

Cao, W., and D.N. Moss. 1989b. Daylength effect on leaf emergence and phyllochron in wheat and barley. Crop Sci. 29:1021-1025.

Cao, W., and D.N. Moss. 1989c. Temperature and daylength interaction on phyllochron in wheat and barley. Crop Sci. 29:1046-1048.

Cao, W., and D.N. Moss. 1991. Phyllochron change in winter wheat with planting date and environmental changes. Agron. J. 83:396401.

Delécolle, R., R.K.M. Hay, M. Guerif, P. Pluchard, and C. VarletGrancher. 1989. A method of describing the progress of apical development in wheat, based on the time-course of organogenesis. Field Crops Res. 21:147-160.

Frank, A.B., and A. Bauer. 1982. Effect of temperature and fertilizer $\mathrm{N}$ on apex development in spring wheat. Agron. J. 74:504-509.

Frank, A.B., and A. Bauer. 1995. Phyllochron differences in wheat, barley, and forage grasses. Crop Sci. 35:19-23 (this issue).

Friend, D.J.C., J.E. Fisher, and V.A. Helson. 1963. The effect of light intensity and temperature on floral initiation and inflorescence development of Marquis wheat. Can. J. Bot. 41:1663-1667.

Grieve, C.M., S.M. Lesch, E.V. Maas, and L.E. Francois. 1993. Salinity effects on leaf appearance in spring wheat. p. 112. In Agronomy abstracts. ASA, Madison, WI.

Gupta, S.C., W.E. Larson, and D.R. Linden. 1983. Tillage and surface residue effects on soil upper boundary temperatures. Soil Sci. Soc. Am. J. 47:1212-1218.

Gupta, S.C., J.K. Radke, and W.E. Larson. 1981. Predicting temperatures of bare and residue covered soils with and without a corn crop. Soil Sci. Soc. Am. J. 45:405-412.

Haun, J.R. 1973. Visual quantification of wheat development. Agron. J. 65:116-119.

Hay, R.K.M., and R. Delécolle. 1989. The setting of rates of development of wheat plants at crop emergence: Influence of the environment on rates of leaf appearance. Ann. Appl. Biol. 115:333-341.

Jones, J.L., and E.J. Allen. 1986. Development in barley (Hordeum sativum). J. Agric. Sci. (Cambridge) 107:187-213.

Kirby, E.J.M. 1993. Effect of sowing depth on seedling emergence, growth and development in barley and wheat. Field Crops Res. 35:101-111.

Kirby, E.J.M., M. Appleyard, and G. Fellowes. 1982. Effect of sowing date on the temperature response of leaf emergence and leaf size in barley. Plant Cell Environ. 5:477-484.

Kirby, E.J.M., M. Appleyard, and G. Fellowes. 1985. Effect of sowing date and variety on main shoot leaf emergence and number of leaves of barley and wheat. Agronomie (Paris) 5:117-126.

Kirby, E.J.M., and B.E. Eisenberg. 1966. Some effects of photoperiod on barley. J. Exp. Bot. 17:204-213.

Kirby, E.J.M., and M.W. Perry. 1987. Leaf emergence rates of wheat in a Mediterranean environment. Aust. J. Agric. Res. 38: 455-464.

Klepper, B., R.K. Belford, and R.W. Rickman. 1984. Root and shoot development in winter wheat. Agron. J. 76:117-122.

Krenzer, E.G., Jr., T.L. Nipp, and R.W. McNew. 1991. Winter wheat mainstem leaf appearance and tiller formation vs. moisture treatment. Agron. J. 83:663-667.

LeCain, D.R., L. Aiguo, J.A. Morgan, and G.S. McMaster. 1992. Long- and short-term acclimation of spring wheat to ambient and elevated $\mathrm{CO}_{2}$ : Gas exchange and development. p. 127. In Agronomy abstracts. ASA, Madison, WI.

Lersten, N.R. 1987. Morphology and anatomy of the wheat plant. p. 33-75. In E.G. Heyne (ed.) Wheat and wheat improvement. 2nd ed. Agron. Monogr. 13. ASA, CSSA, and SSSA, Madison, WI

Longnecker, N., E.J.M. Kirby, and A. Robson. 1993. Leaf emergence, tiller growth, and apical development of nitrogen-deficient spring wheat. Crop Sci. 33:154-160.

Maas, E.V., and C.M. Grieve. 1990. Spike and leaf development in salt-stressed wheat. Crop Sci. 30:1309-1313.

Malvoisin, P. 1984. Organogenesis and growth of the main culm of wheat from sowing to flowering. I. Relationships between leaf growth and the differentiation of young leaves of flowers. Agronomie (Paris) 4:557-564.

Masle, J., G. Doussinault, G.D. Farquhar, and B. Sun. 1989. Foliar stage in wheat correlates better to photothermal time than to thermal time. Plant Cell Environ. 12:235-247.

Masle, J.G., and J.B. Passioura. 1987. The effect of soil strength on the growth of young wheat plants. Aust. J. Plant Physiol. 14:643656.

McMaster, G.S., J.A. Morgan, and W.W. Wilhelm. 1992a. Simulating winter wheat spike development and growth. Agric. For. Meteorol. 60:193-220.

McMaster, G.S., and D.E. Smika. 1988. Estimation and evaluation of winter wheat phenology in the central Great Plains. Agric. For. Meteorol. 43:1-18.

McMaster, G.S., W.W. Wilhelm, and J.A. Morgan. 1992b. Simulating winter wheat shoot apex phenology. J. Agric. Sci. (Cambridge) 119:1-12.

Miglietta, F. 1991a. Simulation of wheat ontogenesis. I. Appearance of main stem leaves in the field. Climate Research 1:145-150.

Miglietta, F. 1991b. Simulation of wheat ontogenesis. II. Predicting dates of ear emergence and main stem final leaf number. Climate Research 1:151-160.

Peterson, C.M., B. Klepper, and R.W. Rickman. 1989. Seed reserves and seedling development in winter wheat. Agron. J. 81:245-251.

Skinner, R.H., and S.R. Simmons. 1993. Modulation of leaf elongation, tiller appearance, and tiller senescence in spring barley by far-red light. Plant Cell Environ. 16:555-562.

Volk, T., and B. Bugbee. 1991. Modeling light and temperature effects on leaf emergence in wheat and barley. Crop Sci. 31:12181224.

Waldman, S.E., R.W. Rickman, B. Klepper, G.S. McMaster, and W.W. Wilhelm. 1991. Sensitivity analysis of SHOOTGRO II and MODWht, two winter wheat growth and development models. p. 25. In Agronomy abstracts. ASA, Madison, WI

Weir, A.H., P.L. Bragg, J.R. Porter, and J.H. Rayner. 1984. A winter wheat crop simulation model without water or nutrient limitations. J. Agric. Sci. (Cambridge) 102:371-382.

Wilhelm, W.W., and G.S. McMaster. 1995. Importance of the phyllochron in studying development and growth in grasses. Crop Sci. 35:1-3 (this issue). 